\title{
Importance of Pre Operative Pulmonary Function Test to Predict Risk of Pulmonary Complications after Abdominal Surgery- An Evidence Based Study
}

\author{
Krupa Pareshbhai Patel ${ }^{1}$, Anjali Bhise ${ }^{2}$ \\ ${ }^{1}$ M.P.T. (Cardiorespiratory), \\ ${ }^{2}$ M.P.T. (Cardiorespiratory), Ph.D. Senior Lecturer, \\ Government Spine Institute and Government Physiotherapy College, Civil Hospital, Asarwa, Ahmedabad.
}

Corresponding Author: Krupa Pareshbhai Patel

\begin{abstract}
Background: Spirometry is a universal, simple, and non-invasive pulmonary function test. Spirometry, along with calculation of the forced expiratory volume in 1 second (FEV1) and forced vital capacity (FVC), is helpful for diagnosing obstructive or restrictive lung disease. Postoperative Pulmonary Complications are defined as unintended pulmonary abnormalities that occur as a result of surgery which cause identifiable dysfunction.

Purpose: To find the evidence showing the importance of pre-operative PFT to predict risk of pulmonary complications after abdominal surgery

Methodology: The study was conducted according to Preferred Reporting Items for systematic reviews and meta-analysis guidelines. Evidences selected since year 20022020 from PubMed, Google Scholar, Physiotherapy Evidence Database (PEDro), ResearchGate and Science Direct. Key words used were: Pulmonary Function Tests, PostOperative Pulmonary Complications, and Abdominal Surgery. Analysis was done using 2 scales: Centre for Evidence-Based Medicine Levels of Evidence Scale. Total 12 articles were found. Among them 10 were selected.
\end{abstract}

Results: 5 articles showed that preoperative PFT is important in prediction of PPCs while the other half concluded that routine preoperative spirometry is not necessary before non-thoracic surgeries.

Conclusion: Based on evidences, in the nutshell it is reviewed that there is controversy regarding the value of preoperative pulmonary functions test in non-thoracic surgeries.

Key words: Pulmonary Function Tests, PostOperative Pulmonary Complications, and Abdominal Surgery

\section{INTRODUCTION}

The term postoperative pulmonary complications (PPCs) encompass almost any complication affecting the respiratory system after anaesthesia and surgery. ${ }^{(1)} \mathrm{A}$ clinically significant PPC can be described as "a pulmonary abnormality that produces identifiable disease or dysfunction that adversely affects a clinical course." (2) While pulmonary changes occur regularly in patients undergoing major surgery, the exact mechanisms by which these combine to lead to clinically significant PPCs in some patients is not currently well understood. The diagnosis of clinically significant PPC may be made by using radiological and bacteriological criteria, clinical signs and symptoms or combination of these and usually include measures of oxygenation, fever, white cell count and presence of infection (e.g. abnormal sputum production or positive sputum microbiology).However, there are inconsistencies in not only which individual criteria compromise the PPC diagnosis but also how these are measured and combined, e.g. the variability of scales used to measure radiographic changes. 
Clearly, the method of defining PPC impacts the reported evidence. ${ }^{(3)}$

The incidence of postoperative pulmonary complications (PPCs) in patients undergoing upper abdominal surgery reportedly ranges between $12 \%$ and $58 \% .^{(4),(5)}$ In addition to surgery related risk factors, advanced age (60 years) is a consistently reported predictor of PPCs. ${ }^{(4),(6),(7)}$ PPCs directly contribute to increased morbidity and mortality, duration of hospital stay and use of resources ${ }^{(7),(8)}$ therefore the need for a preoperative screening test to identify patients at heightened risk of complications has been emphasized. Although there is controversy over the utility of routine spirometry in every patient undergoing upper abdominal surgery, many clinicians order routine spirometry for elderly patients being prepared for upper abdominal surgery. ${ }^{(9)}$
Pulmonary function tests (PFTs) help in the evaluation of the mechanical function of the lungs. Basically, the pulmonary function tests are categorized as volume, flow, or diffusion studies. Diagnosis of pulmonary disease or dysfunction and improvement with treatment win be evaluated as a result of interpreting a patient's pulmonary function tests. ${ }^{(10)}$ Several studies have shown a high prevalence of unsuspected impairment of lung function in surgical patients and suggest that preoperative pulmonary function testing is underutilized. ${ }^{(14)}$

\section{METHODOLOGY}

Study Type: This is an Evidence Based Study conducted according to Prefferred Reporting Items for Systematic Reviews and Meta-analysis (PRISMA) guidelines (Figure 1).

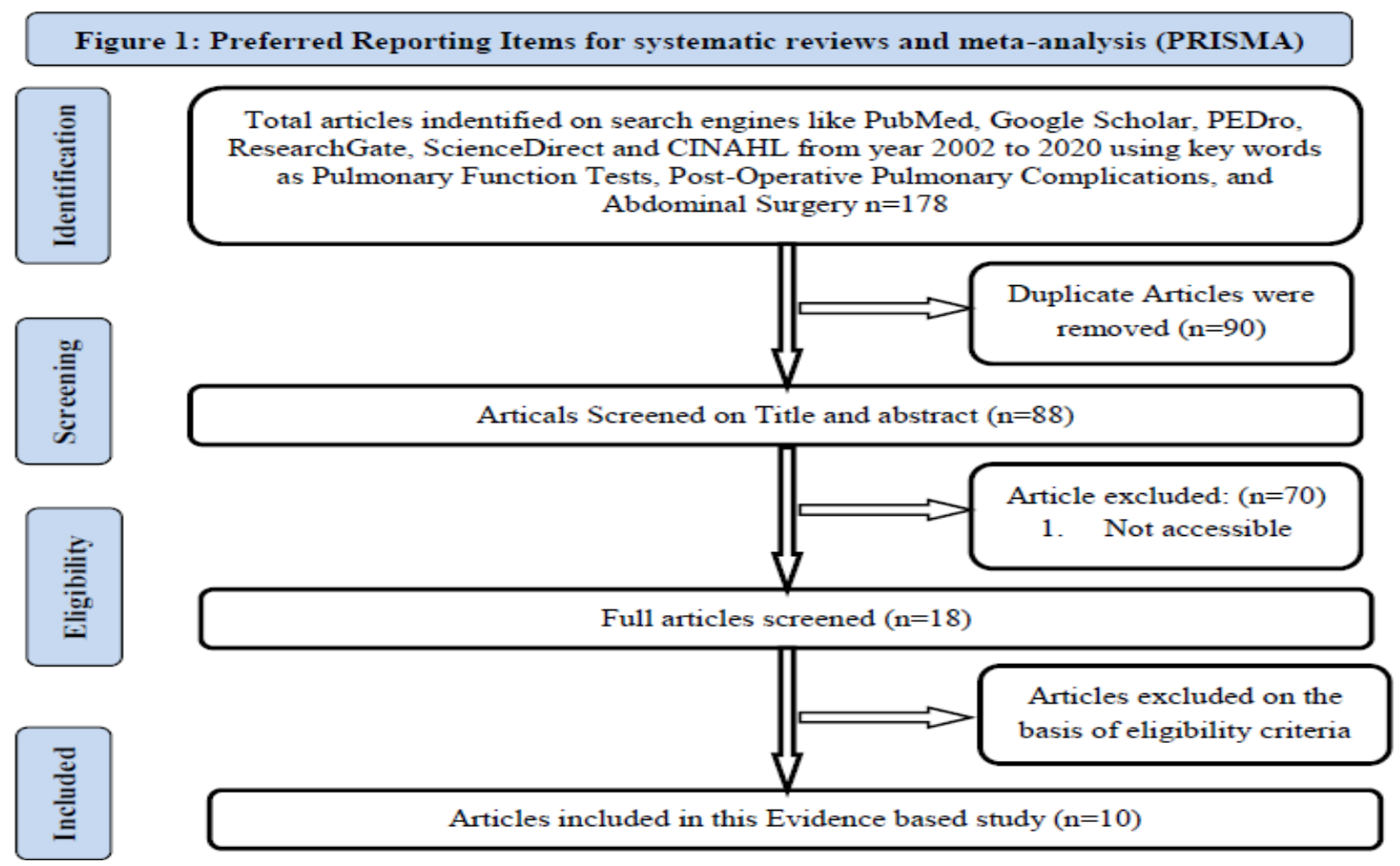

Search strategy: The search engines used for the finding out appropriate articles were: Google Scholar, PubMed, PEDro, ScienceDirect, ResearchGate, CINAHL.

Key words used for the search were: Pulmonary Function Tests, Post-Operative Pulmonary Complications, and Abdominal Surgery
Eligibility criteria: Articles were selected from last 20 years (2002-2021). Total 178 articles were found, out of which 18 articles were relevant and from those 10 articles were included in the study (Table 1). Other articles were excluded because it didn't involve population of abdominal surgery and outcome measures were not related to PPC. 
Data Analysis: All 10 articles were assessed using CEBM and Modified Sackett scales:

1. The CEBM's Levels of Evidence scale: It assesses quality based on study design, which categorize the studies in a scale ranging from 1 to 5 with further subdivision for each.(appendix 1)

2. Modified Sackett Scale Version 4.0. (appendix 2)

Table 1: Characteristics of included studies

\begin{tabular}{|c|c|c|c|c|c|c|}
\hline $\begin{array}{l}\text { Sr } \\
\text { No }\end{array}$ & Title & $\begin{array}{c}\text { Study } \\
\text { design \& } \\
\text { duration }\end{array}$ & $\begin{array}{l}\text { Articles } \\
\text { Or } \\
\text { Sample } \\
\text { Size } \\
\end{array}$ & Outcome measures & Conclusions and relevance & $\begin{array}{l}\text { Level of } \\
\text { evidence }\end{array}$ \\
\hline 1 & $\begin{array}{l}\text { Pre-Operative Pulmonary } \\
\text { Assessment And Risk } \\
\text { Factors For Post- } \\
\text { Operative Pulmonary } \\
\text { Complications Elective } \\
\text { Abdominal Surgery In } \\
\text { Nigeria by Chinyelu } \\
\text { Uchenna et al }{ }^{(12)}\end{array}$ & $\begin{array}{l}\text { Prospective } \\
\text { observationa } \\
1 \text { study }\end{array}$ & 50 & $\begin{array}{l}\text { Post-operative pulmonary } \\
\text { complications. }\end{array}$ & $\begin{array}{l}\text { There was high prevalence of } \\
\text { post-operative pulmonary } \\
\text { Complications in this study. Pre- } \\
\text { operative cough, shortness of } \\
\text { breath, consolidation, low } \\
\text { percentage predicted FEV1 and } \\
\text { FVC were associated with PPCs. }\end{array}$ & 4 \\
\hline 2 & $\begin{array}{l}\text { Value Of Preoperative } \\
\text { Spirometry Test In } \\
\text { Predicting Postoperative } \\
\text { Pulmonary } \\
\text { Complications In High- } \\
\text { Risk Patients After } \\
\text { Laparoscopic Abdominal } \\
\text { Surgery by Tak Kyu Oh } \\
\text { et al.(13) }\end{array}$ & $\begin{array}{l}\text { Retrospectiv } \\
\mathrm{e} \\
\text { observationa } \\
1 \text { study }\end{array}$ & 898 & $\begin{array}{l}\text { The association between } \\
\text { the results of spirometry } \\
\text { tests performed within } 1 \\
\text { month prior to surgery and } \\
\text { the occurrence } \\
\text { of PPC }\end{array}$ & $\begin{array}{l}\text { They concluded that Lower } \\
\text { Preoperative Spirometry FVC } \\
\text { may predict PPCs in high-risk } \\
\text { patients undergoing Laparoscopic } \\
\text { abdominal surgery. FEV1 or } \\
\text { FEV1/FVC were not useful } \\
\text { predictors of PPCs. }\end{array}$ & 4 \\
\hline 3 & $\begin{array}{lr}\text { Is } & \text { preoperative } \\
\text { spirometry a predictive } \\
\text { marker for postoperative } \\
\text { complications } \\
\text { colorectal after } \\
\text { surgery? by Yuki } & \text { Tajima } \\
\text { et al }^{(14)} & \end{array}$ & $\begin{array}{l}\text { Retrospectiv } \\
\text { e study }\end{array}$ & $\begin{array}{c}1236 \\
\text { patients }\end{array}$ & $\begin{array}{l}\text { The postoperative } \\
\text { complications were } \\
\text { Pneumonia, elevated white } \\
\text { blood cell count (WBC) or } \\
\text { Creactive protein (CRP) } \\
\text { level in blood tests, } \\
\text { pneumonia images on a } \\
\text { chest X-ray or Computed } \\
\text { Tomography (CT) scan, } \\
\text { and the need for antibiotics }\end{array}$ & $\begin{array}{l}\text { This study concluded that } \\
\text { Spirometer is useful as a } \\
\text { preoperative examination for } \\
\text { helping to predict pulmonary } \\
\text { complications, especially } \\
\text { postoperative pneumonia, in } \\
\text { Colorectal cancer surgery. }\end{array}$ & 4 \\
\hline 4 & $\begin{array}{lr}\text { Risk Factors for } & \text { Post- } \\
\text { Operative Pulmonary } \\
\text { Complications } r \text { after } \\
\text { Gastrectomy for } & \text { Gastric } \\
\text { Cancer by } & \text { Mikito } \\
\text { Inokuchi et al }^{(15)} & \end{array}$ & $\begin{array}{l}\text { Retrospectiv } \\
\text { e study }\end{array}$ & 24 & $\begin{array}{l}\text { Post-operative pulmonary } \\
\text { complications } \\
\text { development of pneumonia, } \\
\text { macroscopic atelectasis, } \\
\text { pneumothorax, prolonged } \\
\text { mechanical ventilation } \\
\text { (longer than 24h), mass } \\
\text { pleural effusion requiring } \\
\text { puncture, Acute respiratory } \\
\text { distress syndrome (ARDS) } \\
\text { within 30d after surgery. }\end{array}$ & $\begin{array}{l}\text { This study concluded that } \\
\text { extended operating time, total } \\
\text { gastrectomy, and lower predicted } \\
\text { VC (vital capacity) were } \\
\text { independent predictors of PPCs in } \\
\text { patients with gastric cancer who } \\
\text { underwent gastrectomy }\end{array}$ & 4 \\
\hline 5 & $\begin{array}{lr}\text { Pulmonary } & \text { Function } \\
\text { Testing } & \text { and } \\
\text { Complications } & \text { of } \\
\text { Laparoscopic } & \text { Bariatric } \\
\text { Surgery by Astrid van } \\
\text { Huisstede et al }^{(\mathbf{1 6})}\end{array}$ & $\begin{array}{l}\text { Prospective } \\
\text { Observation } \\
\text { al Study }\end{array}$ & 585 & $\begin{array}{l}\text { The cumulative 30-days } \\
\text { postoperative complications } \\
\text { were obtained from the } \\
\text { patient charts. Then the } \\
\text { complications were divided } \\
\text { into pulmonary, surgical, } \\
\text { infectious and other }\end{array}$ & $\begin{array}{l}\text { The subjects with complications } \\
\text { within } 30 \text { days of bariatric surgery } \\
\text { more often have airflow } \\
\text { reversibility or airflow } \\
\text { obstruction. This study further } \\
\text { suggested that randomized } \\
\text { prospective studies are needed to } \\
\text { investigate whether abnormal } \\
\text { pulmonary functions tests could } \\
\text { serve as a guide in patient } \\
\text { selection and optimization of the } \\
\text { preoperative medical condition of } \\
\text { patients undergoing bariatric } \\
\text { surgery. }\end{array}$ & 4 \\
\hline 6 & $\begin{array}{l}\text { Association Of } \\
\text { Preoperative Spirometery } \\
\text { With Cardiopulmonary } \\
\text { Fitness And } \\
\text { Postoperative Outcomes } \\
\text { In Surgical Patients: A } \\
\text { Multicenter Prospective } \\
\text { Cohort Study by Ashwin } \\
\text { Shankar et al (17) }\end{array}$ & $\begin{array}{l}\text { Multicenter } \\
\text { Prospective } \\
\text { Cohort } \\
\text { Study }\end{array}$ & 1200 & $\begin{array}{l}\text { Respiratory morbidity } \\
\text { Pulmonary complications } \\
\text { (pneumonia and respiratory } \\
\text { failure) }\end{array}$ & $\begin{array}{l}\text { FEV1 was not strongly predictive } \\
\text { of respiratory complications in } \\
\text { major elective non cardiac } \\
\text { surgery. }\end{array}$ & 4 \\
\hline
\end{tabular}




\begin{tabular}{|c|c|c|c|c|c|c|}
\hline \multicolumn{7}{|c|}{ Table no 1. Continued... } \\
\hline 7 & $\begin{array}{l}\text { Preoperative Pulmonary } \\
\text { Function Tests Do Not } \\
\text { Predict The Development } \\
\text { Of Pulmonary } \\
\text { Complications After } \\
\text { Electiverrajer } \\
\text { Abdominal Surgery: A } \\
\text { Prospective Cohort Study } \\
\text { by Shinichiro Yokota et } \\
\text { al }{ }^{(18)}\end{array}$ & $\begin{array}{l}\text { Prospective } \\
\text { Cohort } \\
\text { Study }\end{array}$ & $\begin{array}{c}676 \\
\text { patients }\end{array}$ & $\begin{array}{l}\text { They } r \text { considered } \\
\text { postoperative pulmonary } \\
\text { complications as } \\
\text { respiratory failure requiring } \\
\text { mechanical ventilation, } \\
\text { pneumonia, and atelectasis } \\
\text { requiring bronchoscopy, or } \\
\text { pneumothorax or pleural } \\
\text { effusion requiring } \\
\text { percutaneous intervention }\end{array}$ & $\begin{array}{l}\text { Age, duration of surgery, and } \\
\text { blood transfusion with and } \\
\text { without } \% \text { VC (percentage of vital } \\
\text { capacity) had a similar predictive } \\
\text { value of post pulmonary } \\
\text { complications. They suggest that } \\
\text { preoperative PFT does not } \\
\text { significantly improve the ability } \\
\text { to predict the development of } \\
\text { PPC. The results of this study } \\
\text { support discontinuing the practice } \\
\text { of routine. }\end{array}$ & 4 \\
\hline 8 & $\begin{array}{l}\text { Is routine preoperative } \\
\text { spirometry necessary in } \\
\text { elderly patients } \\
\text { undergoing laparoscopy - } \\
\text { assisted gastrectomy? By } \\
\text { Jin Huh et al }{ }^{(19)}\end{array}$ & $\begin{array}{l}\text { Retrospectiv } \\
\text { e Cohort } \\
\text { Study }\end{array}$ & 213 & $\begin{array}{l}\text { Post-Operative Pulmonary } \\
\text { Complications: a clinical } \\
\text { examination of pulmonary } \\
\text { symptoms (e.g., cough, } \\
\text { dyspnea, excessive sputum } \\
\text { production, chest pain, } \\
\text { wheezing, crackles, fever, } \\
\text { chest X-radiography and } \\
\text { analysis of venous white } \\
\text { blood cell count on } \\
\text { postoperative day } 1 \text { or } 2) \text {. }\end{array}$ & $\begin{array}{l}\text { They concluded that preoperative } \\
\text { spirometry results are not reliably } \\
\text { predictive of PPCs, either as } \\
\text { combined or individual lung } \\
\text { function parameters, in patients } \\
\text { aged } 60 \text { years who are scheduled } \\
\text { to undergo LAG (laparoscopy- } \\
\text { assisted gastrectomy). Their } \\
\text { results do not support the use of } \\
\text { routine spirometry to stratify PPC } \\
\text { risk in this surgical population. } \\
\text { According to this study patient's } \\
\text { age is an independent predictor of } \\
\text { PPCs, therefore there should be a } \\
\text { higher expectation of PPCs in } \\
\text { elderly patients (60 years) } \\
\text { undergoing LAG, compared with } \\
\text { a younger population. }\end{array}$ & 4 \\
\hline 9 & $\begin{array}{l}\text { Preoperative Pulmonary } \\
\text { Risk Stratification for } \\
\text { Non cardiothoracic } \\
\text { Surgery: Systematic } \\
\text { Review for the American } \\
\text { College of Physician by } \\
\text { Gerald W. Smetana et } \\
\mathrm{al}^{(7)}\end{array}$ & $\begin{array}{l}\text { Systemic } \\
\text { Review }\end{array}$ & $\begin{array}{c}27 \\
\text { studies }\end{array}$ & - & $\begin{array}{l}\text { According to this systemic review } \\
\text { evidence is insufficient to } \\
\text { determine whether spirometry } \\
\text { provides incremental value as a } \\
\text { tool to estimate postoperative } \\
\text { pulmonary complication risk. The } \\
\text { evidence does not support the use } \\
\text { of routine spirometry to stratify } \\
\text { risk before non-cardiothoracic } \\
\text { surgery. }\end{array}$ & $\mathbf{2 a}$ \\
\hline 10 & $\begin{array}{l}\text { Predicting Pulmonary } \\
\text { Complications after Non } \\
\text { thoracic Surgery: A } \\
\text { Systematic Review of } \\
\text { Blinded Studies by Bruce } \\
\text { W. Fisher et } \mathrm{al}^{(\mathbf{2 0 )}}\end{array}$ & $\begin{array}{l}\text { Systematic } \\
\text { Review of } \\
\text { Blinded } \\
\text { Studies }\end{array}$ & $\begin{array}{c}95 \\
\text { papers }\end{array}$ & - & $\begin{array}{l}\text { This study identified } 16 \text { variables } \\
\text { that predicted postoperative } \\
\text { pulmonary complication } \\
\text { significantly These included } \\
\text { elements of the history(increasing } \\
\text { age, preoperative sputum } \\
\text { production, chronic obuctive } \\
\text { pulmonary disease, Roizen's } \\
\text { Dyspnea Score 1, smoking status, } \\
\text { and American, Society of } \\
\text { Anesthesiologists Score 2), } \\
\text { abnormal findings on the } \\
\text { pulmonary examination, Charlson } \\
\text { Comorbidity Score and Goldman } \\
\text { Risk Index, laboratory findings } \\
\text { (reduced FEV1 or peak expiratory } \\
\text { flow rate, hypoxemia, or } \\
\text { abnormalities on chest } \\
\text { radiography), type of surgery, } \\
\text { duration of anesthesia, and } \\
\text { postoperative nasogastric tube } \\
\text { placement. Also, Several other } \\
\text { variables cited commonly in the } \\
\text { assessment of postoperative } \\
\text { pulmonary complication risk, } \\
\text { such as hypercarbia or } \\
\text { abnormalities on spirometry, were } \\
\text { not identified as useful or } \\
\text { independent predictors. }\end{array}$ & $2 a$ \\
\hline
\end{tabular}




\section{RESULTS}

Evidences were reviewed and analysis was done on the basis of CEBM's Level of Evidence Scale and modified Sackett scale version 4.0.

Total 178 articles were found, out of which 18 articles were relevant and from those 17 articles were included in this evidence-based study and other articles were excluded as per eligibility criteria.

From total 10 studies, there are 2 systematic reviews and their level of evidence was $2 \mathrm{a}$, while 4 were retrospective studies and 4 were prospective observational studies with level of evidence 4. There are two systematic reviews with level of evidence 2 a which does not support the use of routine spirometry to stratify risk before non-cardiothoracic surgery.

The other three one retrospective and two prospective studies with level of evidence 4 suggests that preoperative spirometry values are not strongly associated with occurrence of postoperative pulmonary complications (PPCs). The other five studies two prospective and three retrospective studies suggests that preoperative spirometry values are significantly associated with PPCs. However, lower predicted percentage of VC was found to be significantly associated with occurrence of PPC in most of studies rather than FEV1.

\section{DISCUSSION}

Total 10 studies ( 2 systemic reviews, 4 prospective and 4 retrospective studies) were included in this evidence based research. The methodological qualities of included studies were low to high. The sample size varied from 50 to 1236 patients. There are two strong evidences which do not support the use of routine spirometry to stratify risk before non-cardiothoracic surgery. The other three moderate to low evidences suggests that preoperative spirometry values are not strongly associated with occurrence of postoperative pulmonary complications (PPCs).
There are five moderate to low quality evidences suggesting that preoperative spirometry values are significantly associated with PPCs. However, lower predicted percentage of VC was found to be significantly associated with occurrence of PPC in most of studies rather than FEV1. Abnormal preoperative pulmonary function is more likely to develop PPCs. However, age, ASA (American society of anesthesiologists) class or functional dependence, chronic obstructive pulmonary disease and congestive heart failure were risk factors for development of PPCs.

Two prospective and three retrospective observational studies shows that preoperative spirometry can be helpful to predict PPCs. Chinyelu et al ${ }^{(\mathbf{1 2})}$ concluded that lower predicted FEV1 and FVC were significantly associated with occurrence of PPCs. On the contrary, other three studies suggested that lower predicted vital capacity was independent risk factor for PPCs.

Yuki Tajima et al ${ }^{(13)}$ reported that those who had previous lung problems were reported for wound problems and pulmonary complications, after laparoscopy-assisted distal gastrectomy for gastric cancer. The cause may be hypoxia because of pulmonary problem leading to delay in healing process.

Astrid et al (16) showed that there was almost similar mean BMI (body mass index), $\%$ body fat or abdominal circumference in subjects with or without pulmonary complications. Therefore, fat distribution does not contribute to risk of complications. They also suggested that spirometry cannot only predict PPCs but might predict all complication of bariatric surgery. However, ASA status in this study appeared to be insensitive in predicting complications.

Two of the studies ${ }^{(18)(19)}$ showed that age is independent predictor of PPCs. In patient with age greater than 60 , preoperative spirometry is not predictive of PPCs. Shinichiro et $\mathrm{al}^{(\mathbf{1 8})}$ showed that 3 predictors age, duration of surgery and 
blood transfusion without VC have similar effects in predicting development of PPCs. This suggests that VC does not independently improve ability to predict development of PPCs.

Two studies (14) (19) showed that current smoking has no impact on occurrence of PPCs. Gerald et al ${ }^{(7)}$ reported that preoperative testing may identify subset of high risk patient. However, same risk attributable to abnormal preoperative testing can be obtained by history and physical examination. Thus, patients identified as high risk by spirometry can be equally well identified by clinical evaluation.

\section{CONCLUSION}

Based on evidences on following search engines like Google scholar, PubMed, PEDro, Science Direct, and Research Gate from the year 2002- 2020, it is concluded that there are conflicting evidences regarding the importance of preoperative spirometry to predict postoperative pulmonary complications (PPCs). This may explain PPCs are affected by various factors such as surgery type, surgical site, intraoperative ventilator care strategy, post-operative care as well as other comorbidities.

\section{Abbreviations}

PPCs-Post operative Pulmonary Complication, V/Q-Ventilation and Perfusion, PFT- Pulmonary Function Tests,FEV1-Forced Expiratory Volume In 1second, FVC-Forced Vital Capacity, COPD-Chronic Obstructive Pulmonary Disease, MVV-Minute Ventilation Volume, FEF-Forced Expiratory Flow, PaCO2Partial Pressure Of Carbon Dioxide In Arterial Blood, CXR-Chest X Ray, FiO2Fraction Of Inspired Oxygen, ARDS-Acute Respiratory Distress Syndrome, MGSMelbourne Group Scale, RCT-Randomized Control Trial, PEDro-Physiotherapy Evidence Database, RCT-Randomized Control Trial, CEBM- Center of Evidence Based Medicine, GS-Gosse link Score, BBS-Brooks Bunn Score, ASA- American
Society Of Anaesthesiologists, PCTProspective Controlled Trial, IVIntravenous, WCC-White Cell Count, WBC-White Blood Cell,SPO2-Oxygen Saturation, HDU-High Dependency Unit, CRP- C Reactive Protein, CT-Computed Tomography, BMI- Body Mass Index.

\section{Acknowledgement: None}

Conflict of Interest: There is no conflict of interest.

\section{Source of Funding: None}

Ethical Approval: Ethical approval was not required.

\section{REFERENCES}

1. Miskovic, A. and Lumb, A., 2017. Postoperative pulmonary complications. British Journal of Anaesthesia, 118(3), pp.317-334.

2. O'Donohue, W., 1992. Postoperative pulmonary complications. Postgraduate Medicine, 91(3), pp.167-175.

3. Eleanor Main Linda Denehy. Cardiorespiratory Physiotherapy: Adults And Paediatrics: First South Asia Edition. 1st ed. Elsevier India. 2017.

4. Canet, J., Gallart, L., Gomar, C., Paluzie, G., Vallès, J., Castillo, J., Sabaté, S., Mazo, V., Briones, Z. and Sanchis, J., 2010. Prediction of Postoperative Pulmonary Complications in a Populationbased Surgical Cohort. Anesthesiology, 113(6), pp.1338-1350.

5. Jackson, C., 1988. Preoperative Pulmonary Evaluation. Archives of Internal Medicine,148(10), p.2120.

6. Brooks-Brunn, J., 1997. Predictors of Postoperative Pulmonary Complications Following Abdominal Surgery. Chest, 111(3), pp.564-571.

7. Smetana, G., Lawrence, V. and Cornell, J., 2006. Preoperative Pulmonary Risk Stratification for Noncardiothoracic Surgery: Systematic Review for the American College of Physicians. Annals of Internal Medicine, 144(8), p.581.

8. Dimick JB, Chen SL, Taheri PA, et al 2004. Hospital Costs Associated With Surgical Complications: A Report From 
The Private-Sector. National Surgical Quality

9. J A Brooks-Brunn. Predictors of Postoperative Pulmonary Complications Following Abdominal Surgery. Chest. 1997 Mar;111(3):564-71. doi: 10.1378/ chest.111.3.564.

10. Donna Frownfelter, Elizabeth Dean. Principles and Practice of Cardiopulmonary Physical Therapy: Third Edition. 1996

11. Robert E. Hyatt. Interpretation of Pulmonary Function Tests 4th Edition. 2014

12. Ufoaroh CU, Ele PU, Anyabolu AE, Enemuo EH, Emegoakor CD, Okoli CC, et al 2019. Pre-Operative Pulmonary Assessment and Risk Factors for PostOperative Pulmonary Complications in Elective Abdominal Surgery in Nigeria. Afri Health Sci, 19(1). 1745-1756.

13. Oh TK, Park IS, Ji E, Na H-S 2018. Value of preoperative spirometry test in predicting postoperative pulmonary complications in high risk patients after laparoscopic abdominal surgery. PLoS ONE 13(12):e0209347

14. Yuki Tajima, Masashi Tsuruta, Masashi Yahagi, Hirotoshi Hasegawa, Koji Okabayashi, Kohei Shigeta, Takashi Ishida, and Yuko KitagawaIs 2017. Preoperative spirometry a predictive marker for postoperative complications after colorectal cancer surgery; Japanese Journal of Clinical Oncology, 1-5.

15. Mikito Inokuchi, Kazuyuki Kojima, Keiji Kato, Hirofumi Sugita, and Kenichi Sugihara 2014.Risk Factors for PostOperative Pulmonary Complications after
Gastrectomy for Gastric Cancer Surgical Infections Volume 15, Number 3.

16. Astrid van Huisstede \& Laser Ulas Biter \& Ronald Luitwieler 2013.Pulmonary Function Testing and Complications of Laparoscopic Bariatric Surgery OBES SURG Oct;23(10):1596-603

17. Ashwin Sankar, Kevin E. Thorpe, Andrea S. Gershon, John T. Granton, Duminda N. Wijey sundera 2020. Association of preoperative spirometry with cardiopulmonary fitness and postoperative outcomes in surgical patients. EClinical medicine VOLUME 23, 100396

18. Yokota S, Koizumi M, Togashi K, Morimoto M, Yasuda Y, Sata N, Lefor AK 2020. Preoperative pulmonary function tests do not predict the development of pulmonary complications after elective major abdominal surgery: A prospective cohort study. Int J Surg, 73:65-7.

19. Jin Huh, Tae-Sung Sohn 2013. Is routine preoperative spirometry necessary in elderly patients undergoing laparoscopyassisted gastrectomy? Journal of International Medical Research, 41(4) 1301-1309.

20. Bruce W. Fisher, MD, MSc, Sumit R. Majumdar, MD, MPH 2020 Predicting Pulmonary Complications after Non thoracic Surgery :A Systematic Review of Blinded Studies Am J Med,112:219-225.

How to cite this article: Patel KP, Bhise A. Importance of pre operative pulmonary function test to predict risk of pulmonary complications after abdominal surgery-an evidence based study. International Journal of Science \& Healthcare Research. 2021; 6(3): 236-243. DOI: https://doi.org/10.52403/ijshr.20210741

APPENDIX 1- CEBM'S LEVEL OF EVIDENCE

\begin{tabular}{|l|l|}
\hline Level & \multicolumn{1}{c|}{ Definition } \\
\hline 1a & Systematic reviews of randomized controlled trials \\
\hline 1b & Individual randomized controlled trials \\
\hline 1c & All-or-none studies \\
\hline 2a & Systematic reviews of cohort studies \\
\hline 2b & Individual cohort studies or low-quality randomized controlled trials \\
\hline 2c & Outcome research \\
\hline 3a & Systematic reviews of case-control studies \\
\hline $3 \mathrm{~b}$ & Individual case-control studies \\
\hline 4 & Case series, poorly designed cohort or case-control studies \\
\hline 5 & Animal and bench research, expert opinion \\
\hline
\end{tabular}


Krupa Pareshbhai Patel et.al. Importance of pre operative pulmonary function test to predict risk of pulmonary complications after abdominal surgery-an evidence based study

\section{APPENDIX 2- MODIFIED SACKETT VERSION 4.0}

\begin{tabular}{|l|l|l|}
\hline \multicolumn{1}{|c|}{ Level } & \multicolumn{1}{|c|}{ Research design } & \multicolumn{1}{c|}{ Description } \\
\hline \multirow{2}{*}{ Level 1a } & $\begin{array}{l}\text { Randomized } \\
\text { Controlled Trial (RCT) }\end{array}$ & $\begin{array}{l}\text { More than 1 Higher RCT: Randomized Controlled Trial, PEDro (Physiotherapy Evidence Database) } \\
\text { score } \geq 6 \text {. Includes within subjects comparison with randomized conditions and crossover designs. }\end{array}$ \\
\hline Level 1b & RCT & 1 Higher Randomized Controlled Trial, PEDro score $\geq 6$. \\
\cline { 2 - 3 } & RCT & Lower RCT, PEDro score < 6 \\
& Trial (PCT) & Prospective Controlled Trial (not randomized) \\
\cline { 2 - 3 } & Cohort & $\begin{array}{l}\text { Prospective Longitudinal study using at least 2 similar groups with one exposed to a particular } \\
\text { condition. }\end{array}$ \\
\hline \multirow{3}{*}{ Level 3 } & Case Control 4 & A retrospective study comparing conditions, including historical cohorts. \\
\cline { 2 - 3 } & Pre-Post & $\begin{array}{l}\text { A prospective trial with a baseline measure, intervention, and a post-test using a single group of } \\
\text { subjects. }\end{array}$ \\
\cline { 2 - 3 } & Post-test & $\begin{array}{l}\text { A prospective post-test with two or more groups (intervention followed by post-test and no re-test or } \\
\text { baseline measurement) using a single group of subjects. }\end{array}$ \\
\cline { 2 - 3 } & Case Series & A retrospective study usually collecting variables from a chart review. \\
\hline \multirow{3}{*}{ Level 5 } & Observational & Study using cross-sectional analysis to interpret relations. \\
\cline { 2 - 3 } & Clinical Consensus & $\begin{array}{l}\text { Expert opinion without explicit critical appraisal, or based on physiology, biomechanics or "first } \\
\text { principles". }\end{array}$ \\
\cline { 2 - 3 } & Case Report & Pre-post or case series involving one subject. \\
\hline
\end{tabular}

